\title{
The Freedom Solo pericardial stentless valve: Single-center experience, outcomes, and long-term durability
}

Olaf Stanger, MD, MBA, FETCS, Irina Bleuel, MD, Fabian Gisler, MD, Volkhard Göber, MD, Sylvia Reineke, MD, Brigitta Gahl, MSc, Thierry Aymard, MD, Lars Englberger, MD, Thierry Carrel, MD, and Hendrik Tevaearai, MD, MBA

\begin{abstract}
Objectives: To report our institutional experience and long-term results with the Freedom Solo bovine pericardial stentless bioprosthesis (Sorin Group, Saluggia, Italy).

Methods: Between January 2005 and November 2009, 149 patients (mean age, $73.6 \pm 8.7$ years; 68 [45.6\%] female) underwent isolated $(n=75)$ or combined $(\mathrm{n}=74)$ aortic valve replacement $(\mathrm{AVR})$ using the Solo in our institution. Followup was $100 \%$ complete with an average follow-up time of $5.9 \pm 2.6$ years (maximum, 9.6 years) and a total of 885.3 patient years.
\end{abstract}

Results: Operative (30-day) mortality was $2.7 \%(1.3 \%$ for isolated AVR [n $=1]$ and $4.0 \%$ for combined procedures $[\mathrm{n}=3])$. All causes of death were not valve-related. Preoperative peak (mean) gradients of $74.2 \pm 23.0 \mathrm{~mm} \mathrm{Hg}$ $(48.6 \pm 16.3 \mathrm{~mm} \mathrm{Hg})$ decreased to $15.6 \pm 5.4 \mathrm{~mm} \mathrm{Hg}(8.8 \pm 3.0 \mathrm{~mm} \mathrm{Hg})$ after AVR, and remained low for up to 9 years. The postoperative effective orifice area was $1.6 \pm 0.57 \mathrm{~cm}^{2}, 1.90 \pm 0.45 \mathrm{~cm}^{2}, 2.12 \pm 0.48 \mathrm{~cm}^{2}$, and $2.20 \pm 0.66$ $\mathrm{cm}^{2}$ for the valve sizes $21,23,25$, and 27 , respectively, with absence of severe prosthesis-patient mismatch and $0.7 \%(\mathrm{n}=1)$ experienced moderate prosthesis-patient mismatch. During follow-up, 26 patients experienced structural valve deterioration (SVD) and 14 patients underwent explantation. Kaplan-Meier estimates for freedom from death, explantation, and SVD at 9 years averaged 0.57 (range, 0.47-0.66), 0.82 (range, 0.69-0.90), and 0.70 (range, 0.57-0.79), respectively.

Conclusions: The Freedom Solo stentless aortic valve is safe to implant and shows excellent early and midterm hemodynamic performance. However, SVD was observed in a substantial number of patients after only 5-6 years and the need for explantation increased markedly, suggesting low durability. ( $\mathrm{J}$ Thorac Cardiovasc Surg 2015;150:70-7)

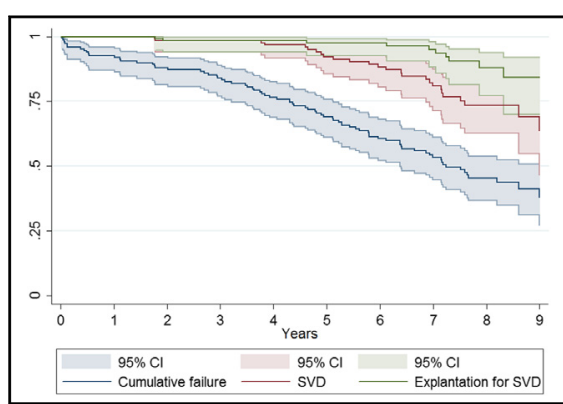

Freedom from SVD, explantation for SVD, and cumulative failure.

\section{Central Message}

The Freedom Solo stentless aortic valve (Sorin Group, Saluggia, Italy) is safe to implant with excellent early and midterm hemodynamic performance. However, structural valve deterioration was observed in a substantial number of patients after only 5 to 6 years and the need for explantation increased markedly, suggesting lower-thanexpected durability.

\section{Perspective}

The Freedom Solo aortic valve (Sorin Group, Saluggia, Italy) is safe to implant and represents the most advanced stentless bioprosthesis available. However, in our single-institution experience, an unexpectedly high amount of valve-independent dysfunction or valve-dependent failure was observed. Any malpositioning and asymmetry between the native anatomy and the stentless tissue valve may cause small distortions and increased chronic mechanical stress, potentially leading to fatigue over time and premature valve deterioration. Root anatomy, correct sizing, symmetric implantation, and tension-free positioning must receive particular attention when using a Solo device.

See Editorial Commentary page 77.

See Editorial page 10.
From the Clinic for Cardiovascular Surgery, Inselspital University Hospital Bern, Bern, Switzerland.

Received for publication Nov 7, 2014; revisions received Jan 8, 2015; accepted for publication Jan 24, 2015; available ahead of print March 11, 2015

\footnotetext{
Address for reprints: Olaf Stanger, MD, MBA, FETCS, Clinic for Cardiovascular Surgery, Inselspital University Hospital, Freiburgstrasse 18, CH-3010 Bern, Switzerland (E-mail: oh.stanger@gmail.com). $0022-5223 / \$ 36.00$

Copyright $(2015$ by The American Association for Thoracic Surgery http://dx.doi.org/10.1016/j.jtcvs.2015.01.060
} 


\section{Abbreviations and Acronyms \\ AVR = aortic valve replacement \\ BSA $\quad=$ body surface area \\ $\mathrm{EOA}=$ effective orifice area \\ EuroScore II = European System for Cardiac \\ Operative Risk Evaluation II \\ GA $=$ glutaraldehyde \\ HCA $=$ homocysteic acid \\ LVEF = left ventricular ejection fraction \\ PPM = prosthesis-patient mismatch \\ SVD $\quad=$ structural valve deterioration}

Stentless bioprostheses were introduced as an attractive alternative to stented valves, combining the advantages of nonobstructive effective orifice area (EOA) and a flexible aortic root that was believed to be essential for natural leaflet stress distribution. Correspondingly, unstented xenografts, with minimal disruption of the aortic root anatomy and function, are expected to reduce dynamic stress on leaflets thereby limiting valve degeneration and failure. ${ }^{1}$ Whereas some earlier stentless porcine root prostheses showed unsatisfactory results with premature failure, ${ }^{2-4}$ more advanced models were aimed at optimizing the tissue type, preservation, and anticalcification treatments, as well as valve design.

The third-generation bovine pericardium Freedom Solo (henceforth Solo) stentless bioprosthesis (Sorin Group, Saluggia, Italy) emerged as a modified version of the Pericarbon Freedom stentless valve in 2004, ${ }^{5}$ and has recently received Food and Drug Administration approval for use in the United States (June 24, 2014). The prosthesis is made of 2 bovine pericardial sheets for supraannular subcoronary implantation using only 1 single suture line, thus reducing crossclamp time. Furthermore, the Solo is manufactured with a unique process that includes homocysteic acid (HCA) as an anticalcification treatment to bind and neutralize free glutaraldehyde (GA) residues for optimal durability.

Numerous reports have documented superior early and midterm hemodynamic results for stentless valve prostheses, including the Solo, in comparison to stented bioprostheses. ${ }^{6-10}$ Although the Solo stentless valve has been used since 2004, no long-term outcome data (beyond the mean $1.2 \pm 0.8$ years) are available. ${ }^{10}$ Thus, we are only now reaching an observation period that allows evaluation of long-term outcome, particularly durability, which will eventually define noninferiority compared with available alternative stented bioprostheses. Because our institution introduced the Solo stentless bioprosthesis at a particularly early stage, we report our operative results with the aim of assessing long-term clinical results; that is, durability and freedom from major adverse events after up to 9.6 years of follow-up.
TABLE 1. Patient preoperative characteristics

\begin{tabular}{|c|c|}
\hline Characteristic & Result \\
\hline Number of patients & 149 \\
\hline Age, y & $73.6 \pm 8.7(46.1-87.4)$ \\
\hline \multicolumn{2}{|l|}{ Gender } \\
\hline Male & $81(54.4)$ \\
\hline Female & $68(45.6)$ \\
\hline Body mass index & $27.0 \pm 5.9(16.9-29.4)$ \\
\hline Body surface area, $\mathrm{m}^{2}$ & $1.82 \pm 0.29(1.27-2.20)$ \\
\hline Diabetes mellitus & $34(22.8)$ \\
\hline Arterial hypertension & $130(87.2)$ \\
\hline Renal impairment & $24(16.1)$ \\
\hline Peripheral artery disease & $62(14.1)$ \\
\hline Carotid stenosis & $14(10.1)$ \\
\hline Chronic obstructive pulmonary disease & $25(9.4)$ \\
\hline Left ventricular ejection fraction, $\%$ & $55.4 \pm 12.3$ \\
\hline History of cerebral events & $17(11.4)$ \\
\hline \multicolumn{2}{|c|}{ New York Heart Association functional class } \\
\hline I & $14(9.4)$ \\
\hline II & $62(41.6)$ \\
\hline III & $54(36.2)$ \\
\hline IV & $19(12.8)$ \\
\hline \multicolumn{2}{|l|}{ Valve pathology } \\
\hline Stenosis & $126(84.6)$ \\
\hline Regurgitation & $10(6.7)$ \\
\hline Combined & $13(8.7)$ \\
\hline \multicolumn{2}{|l|}{ Preoperative rhythm } \\
\hline Sinus data & $120 \pm 80.5$ \\
\hline Chronic atrial fibrillation & $21(14.1)$ \\
\hline Heart block & $2(1.3)$ \\
\hline Paced & $6(4.0)$ \\
\hline \multicolumn{2}{|c|}{$\begin{array}{l}\text { European System for Cardiac Operative Risk } \\
\text { Evaluation II score }\end{array}$} \\
\hline Total & $5.70 \pm 8.88$ \\
\hline Isolated aortic valve replacement & $2.69 \pm 3.36$ \\
\hline Combined procedures & $8.67 \pm 11.34$ \\
\hline
\end{tabular}

Values are presented as mean \pm standard deviation (range) or $\mathrm{n}(\%)$

\section{MATERIALS AND METHODS Patient Population}

Between January 2005 and November 2009, 149 patients (mean age, $73.6 \pm 8.7$ years; 68 female $[45.6 \%])$ underwent isolated $(n=75)$ or combined $(\mathrm{n}=74)$ aortic valve replacement $(\mathrm{AVR})$ using the Solo bovine pericardial stentless valve bioprosthesis in our institution. The decision to use the Solo stentless valve or an alternative, conventional stented prosthesis was at the surgeon's discretion. The Solo stentless valve was not considered suitable in cases with severe calcification of the aortic root, and in patients with true bicuspid valve and ectasia of the ascending aorta. The local ethics committee approved the review of patient data and patient consent was waived for the retrospective analysis. The patients' characteristics are shown in Table 1. One patient underwent operation due to acute bacterial endocarditis (Staphylococcus aureus), and 4 cases were re-do procedures. At the time of surgery, left ventricular ejection fraction (LVEF) $\leq 40 \%$ was present in 24 patients $(16.1 \%)$.

\section{Surgical and Postoperative Management}

AVR procedures were all performed under routine general anesthesia and with a median sternotomy, using standard cardiopulmonary bypass and mild hypothermia $\left(34^{\circ} \mathrm{C}\right)$. Cold blood cardioplegia was routinely 
used for myocardial protection. Aortotomy was performed approximately $1 \mathrm{~cm}$ above the sinotubular junction. The diseased valve was then excised and the annulus carefully decalcified. The Solo valve was implanted without rinsing in the supraannular subcoronary position, with 3 continuous suture lines using 4-0 Prolene polypropylene monofilament (Ethicon, Somerville, NJ) as reported in detail elsewhere. ${ }^{11}$ In brief, sutures started at the base of each sinus, continued to the top of the commissures, and ended with extraaortic fixation. Transesophageal echocardiography was routinely performed intraoperatively before and after AVR to assess the function of the prosthesis. No oral anticoagulation after hospital discharge was required in patients with the Solo valve.

\section{Data Collection, Follow-up, and Definitions}

Perioperative data were retrieved from our prospectively managed institutional database (Dendrite Clinical Systems LTD, Henley-on-Thames, United Kingdom). Closing date for all follow-up investigations was October 1,2014 . Follow-up was $100 \%$ complete with an average follow-up time of $5.9 \pm 2.6$ years (maximum, 9.6 years) and a total of 885.3 patient years.

All patients were routinely examined with transthoracic echocardiography before hospital discharge, at 6 months postoperatively, and yearly thereafter. Intervals were shortened when changes or signs of degeneration were observed. Transvalvular pressure gradients and EOA were calculated using the modified Bernoulli equation and the continuity equation, respectively. Clinical status and adverse events were carefully assessed at each visit or by consultation with the referring physician. Dates of death were confirmed with data from local public authorities.

\section{Data Analysis}

Baseline characteristics and risk factors were defined according to European System for Cardiac Operative Risk Evaluation II (EuroScore II) criteria. Mortality and morbidity (rate of adverse events) were reported according to established guidelines. ${ }^{12,13}$ These guidelines define structural valve deterioration (SVD) as change in function or deterioration of an operated valve resulting from an intrinsic abnormality of the valve that causes stenosis or regurgitation, exclusive of infection or thrombosis. SVD includes wear, fracture, poppet escape, calcification, leaflet tear, stent creep, and suture line disruption of an operated valve. ${ }^{12,13}$ In the absence of established reference values for prosthetic SVD, particularly for stentless valves, we defined intrinsic prosthetic stenosis under normal flow conditions (ejection fraction $>50 \%$ ) and after normal postoperative function, when echocardiographic evidence of distinctive and pronounced degenerative changes (such as severely impaired cusp movements due to thickened, sclerosed, or calcified leaflets) was present (repeat measurements with different investigators) and at least 2 of the following criteria were met: $\geq 3$-fold increase of mean gradients compared with early postoperative measurements (before discharge) in $\geq 25 \mathrm{~mm} \mathrm{Hg}$ mean gradient; EOA $<1.5 \mathrm{~cm}^{2}$, indexed EOA $<0.9 \mathrm{~cm}^{2} / \mathrm{m}^{2}$, and peak velocity $\geq 3 \mathrm{~m} / \mathrm{sec}$ or velocity time integral of 0.5 to 0.25 (velocity time integral was measured in the left ventricular outflow tract and the aortic valve and expressed as left ventricular outflow tract/aortic valve). SVD due to regurgitation was defined as at least moderate regurgitation with pressure half time $\leq 500 \mathrm{~ms}$ and width of vena contracta $\geq 5 \mathrm{~mm}$ (if limited to 1 jet) or diastolic flow reversal in the descending or abdominal aorta in combination with echocardiographic evidence of abnormal prosthesis structure or motion. According to the generally accepted concept of prosthesis-patient mismatch (PPM), the best variable for defining PPM is the ratio of prosthetic EOA to the patient's body surface area (BSA). ${ }^{14}$ PPM was defined as an indexed EOA between $0.85 \mathrm{~cm}^{2} / \mathrm{m}^{2}$ and $0.65 \mathrm{~cm}^{2} / \mathrm{m}^{2}$ (moderate) and $<0.65 \mathrm{~cm}^{2} / \mathrm{m}^{2}$ (severe), which are the established cutoff values for all types of prosthetic valves. ${ }^{14}$

\section{Statistical Analysis}

Demographic data are presented as mean values and standard deviation for continuous variables, and by number and percentages for categorical
TABLE 2. Operative data

\begin{tabular}{|c|c|}
\hline Variable & Result \\
\hline Procedure & 149 \\
\hline Isolated aortic valve replacement & 75 \\
\hline Combined procedures $*$ & 74 \\
\hline Coronary artery bypass grafting & 59 \\
\hline Grafts & $1.9 \pm 1.0$ \\
\hline $\begin{array}{l}\text { Coronary artery bypass graft }+ \text { mitral valve } \\
\text { repair/replacement }\end{array}$ & 5 \\
\hline Coronary artery bypass graft + tricuspid valve repair & 1 \\
\hline $\begin{array}{l}\text { Mitral valve repair/replacement (double valve } \\
\text { replacement) }\end{array}$ & 1 \\
\hline $\begin{array}{l}\text { Mitral valve repair/replacement (double valve } \\
\text { replacement) }+ \text { tricuspid valve repair }\end{array}$ & 1 \\
\hline Tricuspid annuloplasty & 1 \\
\hline Ascendens tube graft & 3 \\
\hline Ablation & 2 \\
\hline Persistent foramen ovale-closure & 8 \\
\hline Other & 4 \\
\hline \multicolumn{2}{|l|}{ Labeled valve size } \\
\hline \#19 & $3(2.0)$ \\
\hline \#21 & $28(18.8)$ \\
\hline \#23 & $44(29.5)$ \\
\hline \#25 & $39(26.2)$ \\
\hline \#27 & $35(23.5)$ \\
\hline \multicolumn{2}{|l|}{ Cardiopulmonary bypass time, min } \\
\hline Isolated procedures & $64 \pm 14$ \\
\hline Combined procedures & $95 \pm 31$ \\
\hline \multicolumn{2}{|l|}{ Crossclamp time, min } \\
\hline Isolated procedures & $47 \pm 13$ \\
\hline Combined procedures & $71 \pm 23$ \\
\hline \multicolumn{2}{|l|}{ Red blood cell units $\dagger$} \\
\hline Isolated procedures & $2.4 \pm 1.3$ \\
\hline Combined procedures & $3.2 \pm 2.1$ \\
\hline \multicolumn{2}{|l|}{ Platelets $\ddagger$} \\
\hline Isolated procedures & $1.5 \pm 0.9$ \\
\hline Combined procedures & $1.8 \pm 1.1$ \\
\hline \multicolumn{2}{|l|}{ 30-d mortality } \\
\hline Isolated procedures & $1 / 75(1.3)$ \\
\hline Combined procedures & $3 / 74(4.0)$ \\
\hline Overall & $4 / 149(2.7)$ \\
\hline
\end{tabular}

Values are presented as $\mathrm{n}$, mean \pm standard deviation, or $\mathrm{n}(\%) . *$ One or more concomitant procedures. $\lceil 51.1 \%$ of patients received $\geq 1$ unit. $\ddagger 14.4 \%$ of patients received $\geq 1$ unit.

variables. Outcome data are presented as operative mortality, defined as death from any cause during or after surgery within 30 days if the patient was discharged, or within any interval if the patient was not discharged, ${ }^{12}$ or as Kaplan-Meier estimates of freedom from the following end points: death, SVD, explantation, thrombosis, endocarditis, or a combination of all. We used multivariate Cox proportional hazard ratio models to identify associations between patient- or procedure-related factors and end points. We used 2 linear mixed models, the first to analyze the effect of the valve replacement on the mean gradient, and the second to analyze the time effect on the mean gradient. Inspecting the residual plots with respect to the random and fixed effects, we detected outliers in the second model corresponding to those patients who developed SVD. Because these patients provide particularly important information, we accepted the larger variance. All $P$ values and confidence intervals are 2 -sided. All statistical analyses were performed using Stata (version 12, StataCorp, College Station, Tex). 


\section{RESULTS \\ Operative Data, Mortality, and Early Complications}

The mean extracorporeal circulation and crossclamp times were, respectively, $64 \pm 14$ minutes (range, $47 \pm$ 13 minutes) and $95 \pm 31$ minutes (range, $71 \pm 23$ minutes) for isolated and combined procedures, with no significant differences among sizes 21, 23, 25, and 27. All patients left the operating room with no or trivial regurgitation.

Overall operative (in-hospital) mortality was $2.7 \%(1.3 \%$ for isolated AVR [n=1] and $4.0 \%$ for combined procedures $[\mathrm{n}=3])$. The corresponding EuroScore II score overestimated the observed mortality considerably (Table 1). Causes of early death were not valve-related; that is, low cardiac output and myocardial infarction $(\mathrm{n}=3)$ and embolism of the basilar artery $(\mathrm{n}=1)$ (Table 2). The 4 nonsurviving patients were older $(77.9 \pm 2.6$ years vs $73.4 \pm 0.7$ years; $P=.038)$ and had a significantly higher EuroScore II score $(20.42 \pm 20.74$ vs $5.29 \pm 8.12 ; P<.001)$ compared with the 145 surviving patients.

In total, 25 patients experienced in-hospital complications (multiple complications possible), including temporary hemofiltration therapy for renal failure (of which 4 patients had renal impairment preoperatively). There were 8 cerebral events, 7 of which were fully reversible by the time of hospital discharge (3 patients had previously experienced cerebral events). Five patients required drainage for pericardial or pleural effusions. There were 2 sternal reexplorations for impaired sternal healing. One permanent pacemaker was implanted due to complete atrioventricular block. Including all patients with these early complications combined, the discharge from hospital occurred after a median length of stay of 10.0 days and 10.5 days for isolated and combined procedures, respectively.

\section{Hemodynamic and Hematologic Data}

The mean preoperative LVEF of $55.4 \% \pm 12.3 \%$ improved to $58.6 \% \pm 11.1 \%, 61.5 \% \pm 12.7 \%, 61.7 \%$ $\pm 10.1 \%, 62.4 \% \pm 10.1 \%$, and $63.0 \% \pm 8.5 \%$ at 6 months, 1, 2, 3, and 4 years postoperatively, respectively $(P<.001)$. Preoperative peak gradients of $76.3 \pm 25.3$ $\mathrm{mm} \mathrm{Hg}$ decreased to $17.9 \pm 9.8 \mathrm{~mm} \mathrm{Hg}$ postoperatively. Mean gradients decreased by $-39.2 \mathrm{~mm} \mathrm{Hg}(P<.001$; $95 \%$ confidence interval $[\mathrm{CI}],-42.4$ to $-35.9 \mathrm{~mm} \mathrm{Hg}$ ) on average in every patient following AVR (Figure 1). Following the first postoperative measurement, the mean gradient increased by $0.94 \mathrm{~mm} \mathrm{Hg}(P<.001 ; 95 \% \mathrm{CI}$, 0.74-1.1) per year, but this was driven by 12 patients who reached a mean gradient $>30 \mathrm{~mm} \mathrm{Hg}$. Gradients showed a nonsignificant trend for lower values with increasing valve size. The postoperative EOA (mean \pm standard deviation) for the valve sizes $21,23,25$, and 27 were $1.67 \pm 0.57$ $\mathrm{cm}^{2}, 1.90 \pm 0.45 \mathrm{~cm}^{2}, 2.12 \pm 0.48 \mathrm{~cm}^{2}$, and $2.20 \pm 0.66$ $\mathrm{cm}^{2}$, respectively. With the definition of PPM as the ratio

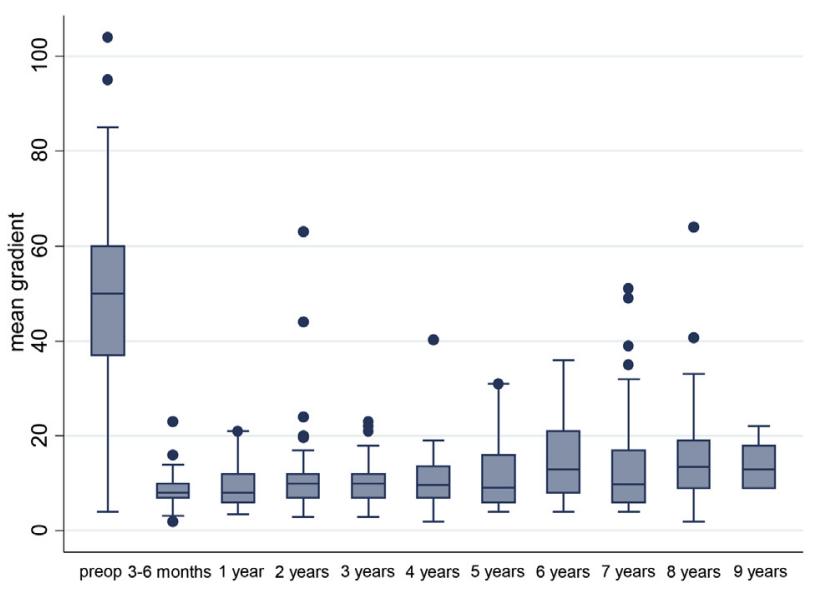

FIGURE 1. Gradients.

of prosthetic EOA to the patient's BSA and the use of established cut-off values, ${ }^{14}$ severe PPM was completely absent, and moderate PPM occurred in 1 patient $(0.7 \%)$; however body mass index was 37.7 and BSA was 2.02 .

Daily platelet counts were performed as part of the standard patient management protocol. Excluding patients with heart failure, infection, and reexploration, minimum platelet counts occurred following an average decrease of $59.9 \%$. After reaching a nadir on the second postoperative day, platelet count returned to baseline value, on average, on the eighth postoperative day. No excess or unexpected bleeding or reexploration was associated with the Solo valve.

\section{Long-Term Survival and Freedom from Major Adverse Events}

Fifty-four patients died during the follow-up period. The survival rate at 7,8 , and 9 years was $66 \%, 59 \%$, and $57 \%$, respectively (see Table 3 and Figure 2). Multivariate Cox regression analysis identified age (hazard ratio [HR], 1.06; 95\% CI, 1.02-1.11; $P=.008)$ and renal dysfunction (HR, 1.94; 95\% CI, 1.02-3.68; $P=.044)$ as parameters independently associated with survival, in contrast to arterial hypertension (HR, 2.75; 95\% CI, 0.85-8.85; $P=.091)$, concomitant coronary artery bypass grafting (HR, 1.18; 95\% CI, 0.70-2.05; $P=.544$ ), combined procedures (HR, 1.12; 95\% CI, 0.65-1.93; $P=.680$ ), and indexed PPM (EOA/BSA as continuous variable: HR, $1.00 ; 95 \%$ CI, 0.73-13.76; $P=1.000$ ).

In 14 patients, the Solo prostheses required explantation due to valve-independent dysfunction $(\mathrm{n}=5)$; that is, thrombus formation, oversizing, aortic dilation, endocarditis, and suture dehiscence or valve-dependent failure $(n=9)$ and all cases are reported separately in great detail elsewhere. ${ }^{15}$ In brief, 5 solo devices required explantation due to severe functional stenosis and gross calcification that was always strikingly severe and included the entire aortic root. Four cases presented with acute regurgitation due to leaflet rupture, all of which were size 23 and 25 
TABLE 3. Estimates on freedom from major adverse events

\begin{tabular}{|c|c|c|c|c|c|c|c|c|c|c|}
\hline e & 1 & 2 & 3 & 4 & 5 & 6 & 7 & 8 & 9 & 10 \\
\hline \multicolumn{11}{|l|}{ Freedom from } \\
\hline D & $\begin{array}{c}0.94 \\
(0.89-0.97)\end{array}$ & $\begin{array}{c}0.91 \\
(0.85-0.94)\end{array}$ & $\begin{array}{c}0.86 \\
(0.80-0.91)\end{array}$ & $\begin{array}{c}0.80 \\
.73-0.86)\end{array}$ & $\begin{array}{c}0.75 \\
(0.67-0.81)\end{array}$ & $\begin{array}{c}0.69 \\
(0.61-0.76)\end{array}$ & $\begin{array}{c}0.66 \\
(0.57-0.73)\end{array}$ & $\begin{array}{c}0.59 \\
(0.50-0.68)\end{array}$ & $\begin{array}{c}0.57 \\
(0.47-0.66)\end{array}$ & $\begin{array}{c}0.57 \\
(0.47-0.66)\end{array}$ \\
\hline SVD & $\begin{array}{c}1.00 \\
(1.00-1.00)\end{array}$ & $\begin{array}{c}0.99 \\
(0.94-1.00)\end{array}$ & $\begin{array}{c}0.99 \\
(0.94-1.00)\end{array}$ & $\begin{array}{c}0.97 \\
(0.92-0.99)\end{array}$ & $\begin{array}{c}0.92 \\
(0.86-0.96)\end{array}$ & $\begin{array}{c}0.88 \\
(0.81-0.93)\end{array}$ & $\begin{array}{c}0.81 \\
(0.72-0.88)\end{array}$ & $\begin{array}{c}0.73 \\
(0.62-0.81)\end{array}$ & $\begin{array}{c}0.70 \\
(0.57-0.79)\end{array}$ & $\begin{array}{c}0.60 \\
(0.37-0.77)\end{array}$ \\
\hline Expla & $\begin{array}{c}0.99 \\
(0.95-1.00)\end{array}$ & $\begin{array}{c}0.96 \\
(0.92-0.99)\end{array}$ & $\begin{array}{c}0.96 \\
(0.92-0.99)\end{array}$ & $\begin{array}{c}0.96 \\
(0.91-0.98)\end{array}$ & $\begin{array}{c}0.95 \\
(0.89-0.97)\end{array}$ & $\begin{array}{c}0.95 \\
(0.89-0.97)\end{array}$ & $\begin{array}{c}0.92 \\
(0.86-0.96)\end{array}$ & $\begin{array}{c}0.85 \\
(0.75-0.92)\end{array}$ & $\begin{array}{c}0.82 \\
(0.69-0.90)\end{array}$ & $\begin{array}{c}0.82 \\
(0.69-0.90)\end{array}$ \\
\hline $\begin{array}{l}\text { Explantation } \\
\text { for SVD }\end{array}$ & $\begin{array}{c}1.00 \\
(1.00-1.00)\end{array}$ & $\begin{array}{r}0.99 \\
(0.94-1)\end{array}$ & $\begin{array}{c}0.99 \\
(0.94-1.00)\end{array}$ & $\begin{array}{c}0.99 \\
(0.94-1.00)\end{array}$ & $\begin{array}{c}0.98 \\
(0.93-0.99)\end{array}$ & $\begin{array}{c}0.98 \\
(0.93-0.99)\end{array}$ & $\begin{array}{c}0.95 \\
(0.88-0.98)\end{array}$ & $\begin{array}{c}0.88 \\
(0.77-0.94)\end{array}$ & $\begin{array}{c}0.84 \\
(0.71-0.92)\end{array}$ & $\begin{array}{c}0.84 \\
(0.71-0.92)\end{array}$ \\
\hline Endocarditis & $\begin{array}{c}0.99 \\
(0.95-1.00)\end{array}$ & $\begin{array}{c}0.99 \\
(0.95-1.00)\end{array}$ & $\begin{array}{c}0.98 \\
(0.93-0.99)\end{array}$ & $\begin{array}{c}0.98 \\
(0.93-0.99)\end{array}$ & $\begin{array}{c}0.98 \\
(0.93-0.99)\end{array}$ & $\begin{array}{c}0.98 \\
(0.93-0.99)\end{array}$ & $\begin{array}{c}0.97 \\
(0.93-0.99)\end{array}$ & $\begin{array}{c}0.97 \\
(0.91-0.99)\end{array}$ & $\begin{array}{c}0.97 \\
(0.91-0.99)\end{array}$ & $\begin{array}{c}0.97 \\
(0.91-0.99)\end{array}$ \\
\hline Thro & $\begin{array}{c}0.99 \\
(0.99-0.93)\end{array}$ & $\begin{array}{c}0.99 \\
(0.95-1.00)\end{array}$ & $\begin{array}{c}0.99 \\
(0.95-1.00)\end{array}$ & $\begin{array}{c}0.99 \\
(0.95-1.00)\end{array}$ & $\begin{array}{c}0.99 \\
(0.95-1.00)\end{array}$ & $\begin{array}{c}0.99 \\
(0.95-1.00)\end{array}$ & $\begin{array}{c}0.99 \\
(0.95-1.00)\end{array}$ & $\begin{array}{c}0.99 \\
(0.95-1.00)\end{array}$ & $\begin{array}{c}0.99 \\
(0.95-1.00)\end{array}$ & $\begin{array}{c}0.99 \\
(0.95-1.00)\end{array}$ \\
\hline $\begin{array}{l}\text { Combined overall } \\
\text { failure }\end{array}$ & $\begin{array}{c}0.93 \\
(0.87-0.96)\end{array}$ & $\begin{array}{c}0.88 \\
(0.82-0.92)\end{array}$ & $\begin{array}{c}0.84 \\
(0.77-0.89)\end{array}$ & $\begin{array}{c}0.77 \\
(0.69-0.83)\end{array}$ & $\begin{array}{c}0.69 \\
(0.61-0.76)\end{array}$ & $\begin{array}{c}0.60 \\
(0.52-0.68)\end{array}$ & $\begin{array}{c}0.53 \\
(0.45-0.61)\end{array}$ & $\begin{array}{c}0.45 \\
(0.36-0.53)\end{array}$ & $\begin{array}{c}0.41 \\
(0.31-0.50)\end{array}$ & $\begin{array}{c}0.35 \\
(0.22-0.48)\end{array}$ \\
\hline
\end{tabular}

Values are presented as estimate (range). $S V D$, Structural valve deterioration.

prostheses. In all these cases of nonsclerotic SVD, vertical tears were notably located in close proximity to the noncoronary/right-coronary commissure, and in our series they occurred, on average, 1.5 years ( 6.0 vs 7.5 years) earlier than explantation for degenerative stenosis. Two patients $(14.3 \%)$ did not survive reoperation: 1 due to sudden cardiac arrest of unknown cause on the eighth postoperative day, and the second because of right ventricular failure.

There were 26 cases of SVD documented during the follow-up period (see Figure 2 and Table 3), of which only 10 underwent reoperation. The remaining 16 patients did not undergo reoperation because of presumed excessive surgical risk, stable valve dysfunction, or because the patient declined surgical treatment. Multivariate Cox regression analysis identified younger age (HR, 0.93; 95\% CI, 0.89-0.97; $P=.002$ ) as an independent predictor for SVD, but not renal dysfunction (HR, 1.15; 95\% CI, $0.26-5.14 ; P=.855$ ), diabetes (HR, $1.39 ; 95 \% \mathrm{CI}, 0.54-$ $3.55 ; P=.495$ ), arterial hypertension (HR, $2.60 ; 95 \% \mathrm{CI}$, $0.620-10.80 ; P=.189$ ), nor PPM (EOA/BSA) as continuous variable (HR, $0.10 ; 95 \% \mathrm{CI}, 0.10-7.26 ; P=.855)$.

Four patients experienced endocarditis, 2 of whom underwent valve explantation and replacement, and the 2 other patients did not undergo reoperation and died 3 and 8 months after diagnosis, respectively. One patient presented with a large thrombotic adhesion on the noncoronary commissure and underwent reoperation 5 months after the primary AVR.

Combining all end points, 78 (52\%) patients experienced an event. We included age, gender, isolated procedure, hypertension, indexed EOA, renal dysfunction, diabetes, and EuroScore II in a Cox regression analysis with the combined end point; only EuroScore II showed an association (HR, 1.02; 95\% CI, 0.02-1.00; $P=.018$ ), suggesting heterogeneous associations between independent variables and individual end points, and indicating that no patient- or procedure-specific parameter alone permits prediction of prosthesis failure.

\section{DISCUSSION}

We are reporting our clinical results in a cohort of 149 patients with the longest follow-up available to date for the third-generation Solo stentless bioprosthesis. Our data suggest that the valve is safe to implant, and provides an excellent early hemodynamic performance. However, freedom from SVD and explantation decreased markedly in our single center study after only 5 to 6 years, implying that the Solo durability is considerably lower than that of conventional stented prostheses.

The Solo represents the most advanced stentless bioprosthesis that combines the single-suture, subcoronary implantation technique with the latest-generation bovine pericardial tissue and a novel anticalcification treatment. Consistent with previous reports, ${ }^{7-10}$ we demonstrate excellent early results of the Solo, relatively easy implantation with acceptable crossclamp times, low gradients, and large EOA, as well as near absence of PPM.

As a unique Solo-dependent side effect, and consistent with previous reports, ${ }^{7,8,10,16,17}$ we observed postoperative thrombocytopenia following implantation, with a mean decrease of $59.9 \%$ in platelet numbers on the second postoperative day, followed by full recovery within 8 days. Importantly, and unexpectedly, Solo-related excess bleeding complications, thromboemboli, or increased reexploration rates have not been observed despite this transient thrombocytopenia. Furthermore, there is no evidence for excess platelet activation, platelet consumption, or change in postoperative platelet function. ${ }^{18}$ Causal hemodynamic flow-dependent mechanical damage appears highly unlikely given the large EOA and low gradients with correctly sized Solo valves, with performances similar to 

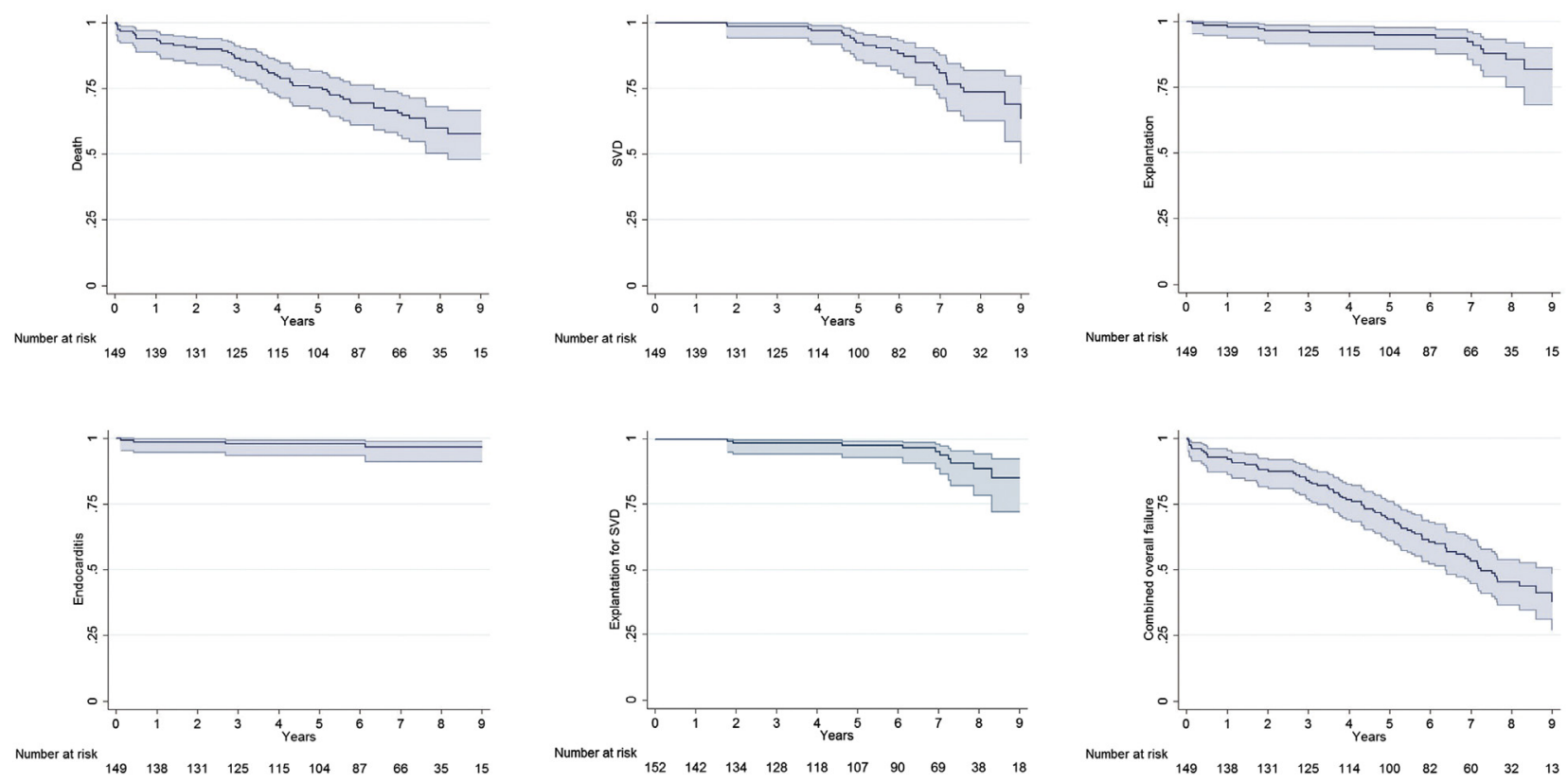

FIGURE 2. Kaplan-Meier estimates for major adverse events. $S V D$, Structural valve deterioration.

native aortic valves at rest and under stress conditions. ${ }^{9,19}$ Contrary to observation, the platelet-damaging effect would be expected to persist if Solo-related hemodynamic stress was causal. In agreement with the suggestion of a patient-independent effect derived from a study with a propensity-matched design, ${ }^{17}$ we hypothesize that a temporary, chemistry-induced lysis leads to lower platelet counts in patients with the Solo device, although the precise mechanism of thrombocytopenia remains to be identified.

A number of stentless valve prostheses have been developed and introduced, but all have been fundamentally different with respect to design, tissue type, and anticalcification treatment, rendering comparisons difficult. Concerns have been raised for stentless prostheses regarding long-term durability, most likely resulting from experiences with earlier (porcine root) models for which, after approximately 10 years, freedom from SVD and reoperation dropped dramatically; for example, the O'Brien (CryoLife, Atlanta, Ga), ${ }^{2}$ Shelhigh (Shelhigh, Inc, Millburn, NJ), ${ }^{3}$ Biocor (St Jude Medical, St Paul, Minn),${ }^{20}$ and Toronto $\mathrm{SPV}^{4}$ (St Jude Medical, St Paul, Minn).

In our single institution experience freedom from thromboembolism and endocarditis was high and comparable to that reported for other stentless and stented bioprosthesis, ${ }^{21-25}$ but freedom from SVD and explantation in our series was much lower than expected. Freedom from explantation after 9 years was only 0.82 in our cohort, compared with 0.97 and 0.98 reported for the conventional stented Hancock II (Medtronic Inc, Minneapolis, Minn) ${ }^{22,23}$ and Perimount Magna (Edwards Lifesciences, Irvine, Calif) ${ }^{23,24}$ bioprostheses at 10 years. In total, 14 prostheses required explantation and all cases are presented individually and in greatest detail elsewhere including full patient histories, post hoc analysis of the transesophageal echocardiography records, intraoperative findings, histologies as well as indications, morphologic, and technical details of reoperations. ${ }^{15}$ Prostheses with tears and cusp ruptures in our series were relatively easy to replace; however, cases with severe calcification turned out to require very difficult and demanding reoperations, confirming a previous report. ${ }^{26}$ The freedom from SVD in our series was only 0.70 after 9 years, substantially lower than the rates of 0.86 to 0.97 reported for conventional stented valves at 10 years; that is, the Hancock $\mathrm{II}^{22,23}$ Mosaic (Medtronic Inc, Minneapolis, Minn), ${ }^{25}$ and Perimount Magna. ${ }^{23}$

The morphologic and hemodynamic criteria defined in this study for SVD indicate intrinsic changes in the valve, suggesting at least moderate aortic stenosis associated with left ventricular hypertrophy, ${ }^{27}$ substantial complications and event rates from aortic stenosis, ${ }^{28}$ impaired event-free survival, and increased overall mortality. ${ }^{29}$ Thus the definition for SVD in our study is rather conservative considering the generally larger EOA and lower gradients of stentless versus stented valves.

In general, SVD is influenced by the tissue structure (eg, bovine vs porcine), the design of the valve, as well as its mechanical wear and stress absorption properties. Notably, chemical fixation and the anticalcification treatment are considered key elements in valve manufacturing aimed at enhancing valve durability and avoiding premature calcification, SVD, and reoperation. ${ }^{30}$ All biological tissue valves, including the Solo, primarily undergo chemical fixation with GA to provide mechanical stability at the 
expense of susceptibility to calcification. In a unique treatment, Sorin uses HCA featuring strong electronegative sulfonic groups as postfixation treatment bonding to neutralize free toxic aldehyde groups in the Solo valve. ${ }^{31}$ In a subcutaneous rat model, GA-HCA-treated bovine pericardium showed less calcification than those treated with GA alone after explantation (14-84 days). ${ }^{31}$ The effectiveness has been questioned because this model ignores mechanical and dynamic stress or blood-surface contact. ${ }^{32}$ In fact, results from the subcutaneous rat model were the exact opposite of those from the blood contact and the pulsatile models, emphasizing the necessity of blood contact in preclinical valve testing. ${ }^{32}$ Furthermore, and perhaps even more important, stentless valve implantation techniques are generally more demanding, less reproducible and standardized, and more dependent on the surgeon's skill and experience. Importantly, the ideal concept of a stentless valve prosthesis assumes that it can replace and imitate a native valve, thus adopting nearly identical functional durability. However, this theoretical idea ignores that the stentless valve may not seat adequately in the native aortic root. In detail, correct sizing and perfectly symmetrical implantation to ensure low leaflet stress is only rarely obtained with heterogeneous strain and elongation, compression, shear, and torsional deformation for the 3 sinuses, ${ }^{1}$ whereas the Solo is constructed perfectly symmetrical and thereby causes stress variations on the leaflets. ${ }^{1}$ In the sheep model, the left and noncoronary sinuses were found to undergo clockwise torsion during the ejection phase, whereas the right sinus undergoes counterclockwise torsion. ${ }^{1}$ This puts stress on the noncoronary commissure/right coronary commissure and could explain why tears were predominantly seen close to this particular location. Any malpositioning and asymmetry between the native anatomy and the stentless tissue valve may cause small distortions with eccentric regurgitation and increased chronic mechanical stress, potentially leading to fatigue over time and premature valve deterioration. ${ }^{33}$ Given the large individual variability in root anatomy, particularly of the noncoronary sinus, which is usually larger than the left and right coronary sinuses (with a larger volume, increased height, width, leaflet size, and thickness), ${ }^{1}$ symmetric implantation, and tension-free positioning can hardly be guaranteed. As a consequence, the observation of root anatomy, correct sizing, and symmetric implantation of the Solo must be given particular attention.

\section{Limitations}

At the time of introduction of the Solo stentless prosthesis, no prior experience was available, and surgeons were engaged in proctoring and teaching, which could have influenced patient selection and technical precision. This study was not designed to investigate the cause of Solo-associated postoperative thrombocytopenia or the structural cardiac changes; that is, the mass regression and its influence on survival. With regard to long-term adverse events, not all causes of death could be clarified. However, it must be expected that SVD in some patients contributed to premature death, particularly because two-thirds of patients diagnosed with SVD did not undergo reoperation for various reasons, and concomitant procedures do not fully explain the difference in mortality between isolated and combined procedures. Thus, competing events may potentially have influenced the assessment of other aortic-valve-related adverse events. We combined all end points to evaluate overall successful AVR with the Solo stentless prosthesis; albeit at the cost of losing clinically relevant information. Because our data reports outcomes from a single institution, we caution a premature final conclusion regarding the Solo; additional data from other centers are warranted to help to determine long-term durability of the Solo prosthesis.

\section{CONCLUSIONS}

The Solo stentless valve is safe to implant and shows excellent hemodynamic performance as well as early and midterm results. There were 26 cases of SVD during the follow-up period. Multivariate Cox regression analysis identified only younger age as an independent predictor for SVD, but not renal dysfunction, diabetes, arterial hypertension, nor PPM as continuous variables. However, actuarial freedom from SVD and explantation decreased markedly after only 5 to 6 years and was only $70 \%$ and $82 \%$ at 9 years, implying that the Solo durability is lower than that of conventional stented prostheses in our institution.

\section{Conflict of Interest Statement}

Authors have nothing to disclose with regard to commercial support.

The authors thank Sarah Longnus, Dorothee Keller, Marija Trojancevic, Laetitia Krummen-Bayard, Monika Sperisen, Bettina Kohler, and Sara Baumberger for providing valuable support in conducting this study and preparation of the manuscript.

\section{References}

1. Dagum P, Green GR, Nistal FJ, Daughters GT, Timek TA, Foppiano LE, et al Deformational dynamics of the aortic root: modes and physiologic determinants Circulation. 1999;100:II54-62.

2. Pavoni D, Badano LP, Ius F, Mazzaro E, Frassani R, Gelsomino S, et al. Limited long-term durability of the Cryolife O'Brien stentless porcine xenograft valve. Circulation. 2007;116:1307-13.

3. Carrel TP, Schoenhoff FS, Schmidli J, Stalder M, Eckstein FS, Englberger L. Deleterious outcome of No-React-treated stentless valved conduits after aortic root replacement: why were warnings ignored? J Thorac Cardiovasc Surg. 2008; $136: 52-7$.

4. David TE, Feindel CM, Bos J, Ivanov J, Armstrong S. Aortic valve replacement with Toronto SPV bioprosthesis: optimal patient survival but suboptimal valve durability. J Thorac Cardiovasc Surg. 2008;135:19-24.

5. Repossini A, Kotelnikov I, Bouchikhi R, Torre T, Passaretti B, Parodi O, et al. Single-suture line placement of a pericardial stentless valve. J Thorac Cardiovasc Surg. 2005;130:1265-9.

6. Funder JA. Current status on stentless aortic bioprosthesis: a clinical and experimental perspective. Eur J Cardiothorac Surg. 2012;41:790-9. 
7. Thalmann A, Kaiblinger J, Krausler R, Pisarik H, Veit F, Taheri N, et al. Clinical experience and mid-term results with the Freedom SOLO stentless aortic valve in 277 consecutive patients. Ann Thorac Surg. 2014;98:1301-7.

8. Iliopoulos DC, Deveja AR, Androutsopoulou V, Filias V, Kastelanos E, Satratzemis V, et al. Single-center experience using the Freedom SOLO aortic bioprosthesis. J Thorac Cardiovasc Surg. 2013;146:96-102.

9. Repossini A, Rambaldini M, Lucchetti V, Da Col U, Cesari F, Mignosa C, et al. Early clinical and haemodynamic results after aortic valve replacements with the Freedom SOLO bioprosthesis (experience of Italian multicenter study). Eur J Cardiothorac Surg. 2012;41:1104-10.

10. Beholz S, Repossini A, Livi U, Schepens M, El Gabry M, Matschke K, et al. The Freedom SOLO valve for aortic valve replacement: clinical and hemodynamic results from a prospective multicenter trial. J Heart Valve Dis. 2010;19:115-23.

11. Stanger O, Tevaerarai H, Carrel T. The Freedom SOLO bovine pericardial stentless valve. Res Rep Clin Cardiol. 2014;5:1-13.

12. Edmunds LH, Clark RE, Cohn LH, Miller DC, Weisel RD. Guidelines for reporting morbidity and mortality after vardiac valvular operations. Ann Thorac Surg. 1988;46:257-9.

13. Vahanian A, Alfieri O, Andreotti F, Artunes MJ, Baron Esquivias G, Baumgartner H, et al. Guidelines on the management of valvular heart disease (version 2012): the Joint Task Force on the Management of Valvular Heart Disease of the European Society of Cardiology (ESC) and the European Association for Cardio-Thoracic Surgery (EACTS). Eur J Cardiothorac Surg. 2012;42:S1-44.

14. Pibarot P, Dumesnil JG. Prosthesis-patient mismatch: definition, clinical impact, and prevention. Heart. 2006;92:1022-9.

15. Stanger O, Bleuel I, Reineke S, Banz Y, Erdoes G, Tevaearai H, et al. Pitfalls and premature failure of the Freedom SOLO stentless valve. Eur J Cardiothorac Surg. December 27, 2014 [Epub ahead of print].

16. Pozzoli A, De Maat GE, Hillege HL, Boogaard JJ, Natour E, Mariani MA. Severe thrombocytopenia and its clinical impact after implant of the stentless Freedom Solo bioprosthesis. Ann Thorac Surg. 2013;96:1581-6.

17. Piccardo A, Rusinaru D, Petitprez B, Marticho P, Vaida I, Tribouilloy C, et al. Thrombocytopenia after aortic valve replacement with freedom solo bioprosthesis: a propensity study. Ann Thorac Surg. 2010;89:1425-30.

18. Tarzia V, Bottio T, Buratto E, Spiezia L, Simioni P, Gerosa G. Freedom Solo stentless aortic valve: quantitative and qualitative assessment of thrombocytopenia. Ann Thorac Surg. 2011;92:1935.

19. Khoo JP, Davies JE, Ang KL, Galinanes M, Chin DT. Differences in performance of five types of aortic valve prostheses: haemodynamic assessment by dobutamine stress echocardiography. Heart. 2013;99:41-7.

20. Dellgren G, Eriksson MJ, Brodin LA, Rådegran K. Eleven years' experience with the Biocor stentless aortic bioprosthesis: clinical and hemodynamic followup with long-term relative survival rate. Eur J Cardiothorac Surg. 2002;22:912-21.
21. Desai ND, Merin O, Cohen GN, Herman J, Mobilos S, Sever JY, et al. Long-term results of aortic valve replacement with the St. Jude Toronto stentless porcine valve. Ann Thorac Surg. 2004; 78:2076-83.

22. David TE, Armstrong S, Maganti M. Hancock II bioprosthesis for aortic valve replacement: the gold standard of bioprosthetic valves durability? Ann Thorac Surg. 2010;90:775-81

23. Chan V, Kulik A, Tran A, Hendry P, Masters R, Mesana TG, et al. Long-term clinical and hemodynamic performance of the Hancock II versus the Perimount aortic bioprostheses. Circulation. 2010;122:S10-6.

24. Dellgren G, David TE, Raanani E, Armstrong S, Ivanov J, Rakowski H. Late hemodynamic and clinical outcomes of aortic valve replacement with the Carpentier-Edwards Perimount pericardial bioprosthesis. J Thorac Cardiovasc Surg. 2002; 124:146-54.

25. Celiento M, Ravenni G, Milano AD, Pratali S, Scioti G, Nardi C, et al. Aortic valve replacement with the Medtronic Mosaic bioprosthesis: a 13-year followup. Ann Thorac Surg. 2012;93:510-5.

26. Borger MA, Prasongsukarn K, Armstrong S, Feindel CM, David TE Stentless aortic valve reoperations: a surgical challenge. Ann Thorac Surg. 2007;84:737-44.

27. Cramariuc D, Rieck AE, Staal EM, Wachtell K, Eriksen E, Rosseb $\varnothing$ AB, et al Factors influencing left ventricular structure and stress-corrected systolic function in men and women with asymptomatic aortic valve stenosis (a SEAS Substudy). Am J Cardiol. 2008;101:510-5.

28. Kennedy KD, Nishimura RA, Holmes DR, Bailey KR. Natural history of moderate aortic stenosis. J Am Coll Cardiol. 1991;17:313-9.

29. Rosenhek R, Klaar U, Schemper M, Scholten C, Heger M, Gabriel H, et al. Mild and moderate aortic stenosis. Natural history and risk stratification by echocardiography. Eur Heart J. 2004:25:199-205.

30. Schoen FJ, Levy RJ. Calcification of tissue heart valve substitutes: progress towards understanding and prevention. Ann Thorac Surg. 2005;79:1072-80.

31. Valente M, Pettenazzo E, Thiene G, Molin GM, Martignago F, De Giorgi G, et al Detoxified glutaraldehyde cross-linked pericardium: tissue preservation and mineralization mitigation in a subcutaneous rat model. J Heart Valve Dis. 1998;7:283-91.

32. Ozaki S, Herijgers P, Flameng W. Influence of blood contact on the calcification of glutaraldehyde-pretreated porcine aortic valves. Ann Thorac Cardiovasc Surg. 2003;9:245-52.

33. Grande KJ, Cochran RP, Reinhall PG, Kunzelmann KS. Stress variations in the human aortic root and valve: The role of anatomic asymmetry. Ann Biomed Eng. 1998;26:534-45.

Key Words: aortic valve, stentless, bioprosthesis, cardiac surgery, valve surgery

\title{
EDITORIAL COMMENTARY
}

\section{Getting to the (aortic) root of the problem}

\author{
Abe DeAnda, Jr, MD, and Leora B. Balsam, MD
}

See related article on pages 70-7.

From the Department of Cardiothoracic Surgery, New York University-Langone Medical Center, New York, NY.

Disclosures: Authors have nothing to disclose with regard to commercial support. Received for publication March 23, 2015; accepted for publication March 25, 2015; available ahead of print April 18, 2015
Aortic valve replacement remains a process in evolution, with the ideal substitute always seemingly on the horizon. In recent years, great energy and effort have been expended

\footnotetext{
Address for reprints: Abe DeAnda, Jr, MD, New York University-Langone Medical Center, 530 First Ave, Suite 9V, New York, NY 10016 (E-mail: abe.deanda@ nyumc.org).

J Thorac Cardiovasc Surg 2015;150:77-8

$0022-5223 / \$ 36.00$

Copyright (c) 2015 by The American Association for Thoracic Surgery

http://dx.doi.org/10.1016/j.jtcvs.2015.03.054
} 